\title{
Pelvis Cancer pT1 TNM Finding v8
}

National Cancer Institute

\section{Source}

National Cancer Institute. Pelvis Cancer pT1 TNM Finding v8. NCI Thesaurus. Code C136594.

Pelvis cancer with tumor confined to one pelvic segment with no extraosseous extension. (from AJCC 8th Ed.) 